\title{
Improved curve number selection for runoff prediction
}

\author{
J. Perrone and C.A. Madramootoo
}

\begin{abstract}
The three antecedent moisture conditions used in the SCS (Soil Conservation Service) curve number method of surface runoff volume prediction have been shown to be inapplicable in humid regions such as the Ottawa - St. Lawrence Lowlands. The antecedent precipitation index is an alternative indicator of soil moisture. Using a hydrologic database, calibration curves were developed to correlate antecedent precipitation index to the SCS curve number. Curve numbers were then input to the AGNPS hydrologic model. When compared to the three antecedent moisture conditions in the SCS curve number method, use of antecedent precipitation index as a soil moisture indicator considerably improved surface runoff volume simulations. However, peak flow was generally overpredicted by the AGNPS model.
\end{abstract}

Key words: AGNPS, antecedent moisture, curve number, peak flow, surface runoff, hydrologic modeling, precipitation.

Résumé : Les recherches ont déjà démontré que les trois conditions antérieures d'humidité de la méthode numéro de courbe SCS (Soil Conservation Service) ne sont pas applicables aux régions humides comme les terres basses du fleuve St. Laurent. L'indice de pluie antécédente est un indicateur d'humidité alternatif. Utilisant une base de données hydrologiques, des courbes de calibration ont été développés pour relier l'indice de pluie antécédente aux numéros de courbe SCS. Ces numéros de courbe ont été introduis dans le modéle hydrologique AGNPS. En comparaison aux trois conditions antérieures d'humidité SCS, l'utilisation de l'indice de pluie antécédente a amélioré considérablement les simulations des volumes d'écoulements d'eau de surface. En générale, les débits de pointes ont été sur-estimé par le modéle AGNPS.

Mots clés : AGNPS, débit de pointe, écoulement d'eau de surface, humidité antérieure, modèlisation hydrologique, numéro de courbe, précipitation.

\section{Introduction}

Runoff simulation is an essential component of any hydrologic modeling effort. Some hydrologic models can be used to estimate the impact of agricultural practices on runoff and erosion, and assist in identifying areas with a high potential for excess runoff and water quality degradation. However, owing to the great inherent variability between hydrologic and climatic settings, modification of input data is sometimes necessitated for such models to be successfully applied to regions of diverse topography, land use, soil types, and storm types.

There are many hydrologic/water quality models such as CREAMS (Knisel 1980), GLEAMS (Leonard et al. 1986), and AGNPS (Young et al. 1985). These models are widely used and generally require knowledge of such watershed characteristics as topography, channel network, soil properties, and land use. Rainfall data are also required by such models in order to simulate runoff, sediment, and nutrient transport. All of the above models use the SCS (Soil Conser-

Received May 13, 1997.

Revised manuscript accepted January 27, 1998.

J. Perrone and C.A. Madramootoo. Department of Agricultural and Biosystems Engineering, Macdonald Campus of McGill University, 21111 Lakeshore Road, Ste. Anne de Bellevue, QC H9X 3V9, Canada.

Written discussion of this article is welcomed and will be received by the Editor until March 31, 1999 (address inside front cover). vation Service) curve number method to estimate surface runoff volume. However, the SCS curve number method has been shown to be inappropriate for runoff volume prediction in various regions (Bales and Beston 1982; Yoo et al. 1993), including Quebec (Madramootoo and Enright 1988).

Therefore, the main objective of this study was to develop an alternative method of SCS curve number selection for the humid regions in Quebec.

\subsection{The SCS curve number method}

The SCS curve number method uses the following equation to estimate surface runoff volume as a depth over the drainage area:

$$
\text { [1] } Q=\frac{(P-0.2 S)^{2}}{(P+0.8 S)}
$$

where $Q$ is surface runoff (mm), $P$ is rainfall $(\mathrm{mm})$, and $S$ is a retention parameter (mm) (U.S. Department of Agriculture 1972). The retention parameter is defined as

[2] $S=\frac{25400}{\mathrm{CN}}-254$

SCS curve numbers were developed empirically using data collected from research watersheds in the United States. Chen (1981) stated that there is no way of knowing how the relationships between the three antecedent moisture conditions (AMC) were developed. The rationale for the 5-day AMC criterion (see Table 1) is also unclear (Enright 1988). 
Table 1. SCS curve number antecedent moisture conditions (AMC). ${ }^{*}$

\begin{tabular}{llll}
\hline & & \multicolumn{2}{l}{ 5-day antecedent rainfall $(\mathrm{mm})$} \\
\cline { 2 - 3 } AMC & General description & Dormant season & Growing season \\
\hline I & Optimum soil condition from about lower plastic limit to & $<13$ \\
$\quad$ wilting point & & $13-28$ \\
II & Average value for annual floods & $>28$ & $36-53$ \\
III & Heavy rainfall or light rainfall and low temperatures within & $>53$ \\
& 5 days prior to the given storm & & \\
\hline
\end{tabular}

"Source: Schwab et al. 1981.

One of the major weaknesses of the SCS curve number method is the discrepancy between published values and those determined adequate for use in the field (Smith and Eggert 1978). Incorrect curve numbers can lead to gross errors in runoff estimation (Yoo et al. 1993). Hawkins (1979) stated that antecedent moisture condition variations are not well represented by the SCS method. Hjelmfelt et al. (1982) suggested that the interaction of variables such as individual storm characteristics, tillage, plant growth, and temperature with antecedent moisture were considerable enough to prohibit the use of AMC alone to explain back-calculated curve number variation (Yoo et al. 1993). Using 585 storm events from 36 watersheds, Bales and Beston (1982) found that when using AMC II exclusively, the curve number method underpredicted observed runoff volumes $93 \%$ of the time. Madramootoo and Enright (1988) demonstrated that the SCS curve number method is inappropriate for estimating surface runoff in the Ottawa - St. Lawrence region.

\subsection{The antecedent precipitation index}

Several variations to the SCS curve number method have been proposed over the years. Steichen (1983) showed that curve numbers varied seasonally with tillage practice. Modifications to the SCS method were necessitated in order to simulate runoff in the coastal plains of the eastern United States (Sheridan and Shirohammadi 1986). Hauser and Jones (1991) incorporated the log-normal probability distribution of the retention parameter to determine curve numbers for the three antecedent moisture conditions.

An alternate method of determining antecedent moisture is described by the antecedent precipitation index, $P_{\mathrm{a}}$ (Bruce and Clark 1966). This index is calculated from rain or snowfall data for a number of days before a given event. The antecedent precipitation index for day $0, P_{\mathrm{a} 0}$, is given by

$$
\text { [3] } \quad P_{\mathrm{a} 0}=k P_{1}+k^{2} P_{2}+\ldots+k^{n} P_{n}
$$

where $P_{1}, P_{2}, \ldots, P_{n}$ are precipitation depths $1,2, \ldots, n$ days prior to the event and $k$ is a constant $(k<1)$.

Foroud (1978) demonstrated that the antecedent precipitation index (API) was an appropriate indicator of antecedent moisture conditions for Quebec watersheds when applied to infiltration equations. Monfet (1979) suggested using the antecedent precipitation index and the time of year to modify the SCS curve number method for Quebec conditions. The antecedent precipitation index was also used by Hoang (1979) to distinguish between three antecedent precipitation conditions:

- Condition 1: $0 \leq \mathrm{API} \leq 15 \mathrm{~mm}$

- Condition 2: $15 \leq \mathrm{API} \leq 30 \mathrm{~mm}$

\section{- Condition 3: API > $30 \mathrm{~mm}$}

Using these criteria, empirical equations describing runoff as a function of total rainfall were developed for watersheds in the Estrie region located on the south shore of the St. Lawrence River. Three formulae were developed, one for each API condition. Values of 0.85 for $k$ and 14 for $n$ were deemed adequate for Quebec watersheds (Monfet 1979). Parameter values must be determined empirically and are dependent on hydrologic and climatic conditions.

The specific objectives of this study were to develop a relationship between curve numbers and antecedent precipitation index, and then evaluate the predictive capabilities of the AGNPS model using antecedent precipitation index as the soil moisture indicator.

\section{Materials and methods}

Rainfall and runoff data were measured at the St. Esprit watershed located approximately $50 \mathrm{~km}$ northeast of Montreal (Fig. 1). The St. Esprit watershed is $26.1 \mathrm{~km}^{2}$ in area. Roughly 1659 ha (63.6\%), representing 25 farms, are in crop production; approximately $61 \%$ of the cropped area is under grains or soya, with a majority of this percentage $(37.8 \%)$ representing corn. The remaining area is covered by 575 ha (22\%) of forested and 376 ha $(14.4 \%)$ of noncropped land. Land use was determined through interpretation of aerial photographs. Soil textures in the watershed are variable, with the majority of crop production occurring on heavier soils (Lapp 1996). The topography is flat to rolling with the majority of cultivated land having slopes of less than $3 \%$ and rarely exceeding $5 \%$. The length of the main channel to the outlet is approximately $9 \mathrm{~km}$, traversing an elevation difference of $40 \mathrm{~m}$. The watershed's climate is temperate. Average annual precipitation, potential evapotranspiration, and temperature are $1087 \mathrm{~mm}, 572 \mathrm{~mm}$, and $5.2^{\circ} \mathrm{C}$, respectively (MEF 1995).

In the winter of 1993-1994, a range of hydrometeorological monitoring equipment was installed in the basin. The equipment installed at the basin outlet included a tipping bucket rain gauge, water and air temperature sensors, a submersible pressure transducer installed on the stream bed bottom, an ultrasonic level sensor mounted over the outlet culvert, a datalogger located in the gauging station to record and store data from all instruments, and a backup system that independently measures water level and flow velocity and relays these data to the primary datalogger. The meteorological station was equipped with sensors for air and soil temperature, solar radiation, wind speed and direction, snow accumulation, as well as a tipping bucket rain gauge and a 
Fig. 1. St. Esprit watershed location and description.

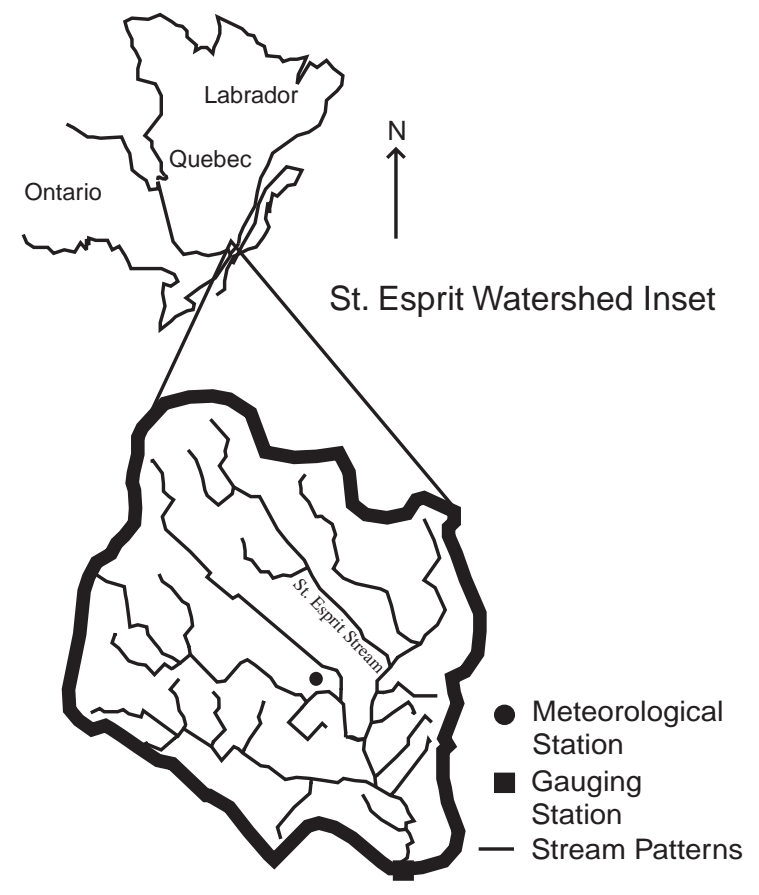

digital datalogger. The locations of both stations are shown in Fig. 1.

A rating curve was developed for the stream at the watershed outlet. Stream velocities were measured at the control section for various flow depths. Results were used to generate a rating curve that was programmed into the datalogger to calculate and store discharge data at 15 min intervals.

\subsection{Hydrologic modeling effort}

AGNPS is an event-based non-point-source pollution model specifically developed to evaluate agricultural watersheds (Young et al. 1989). The model can simulate surface runoff, as well as non-point sediment, nutrient (nitrogen and phosphorus), and pesticide transport. AGNPS also provides for input of sediment and nutrient point-sources such as animal feedlots (Young et al. 1989). The model does not simulate runoff hydrographs. Results are output in the form of hydrologic and pollutant loads exiting individual cells, and, ultimately, as total yields at the watershed outlet.

The model uses a grid system which requires that a given watershed area be divided into cells of a predetermined size. The cells are arrayed from the watershed's upper left-hand corner and are numbered from left to right. A maximum of 28000 cells can be used. Most watershed characteristics (e.g., curve number, slope, universal soil loss equation factors) are expressed at the cell level (Young et al. 1994).

Calculations made by AGNPS are performed in loops or stages. Initial calculations, such as estimates for surface runoff depth and time of concentration for all cells, are made in the first loop (Young et al. 1987). Calculation of overland flows leaving primary cells are then performed during the second loop; primary cells are defined as those into which no other cell drains (Young et al. 1987). Surface runoff is routed through the watershed in the third loop.

Runoff estimates are based on the SCS curve number method. Peak flow is calculated using the following empiri- cal relationship developed for the CREAMS model by Smith and Williams (1980):

$$
Q_{\mathrm{p}}=3.79 A^{0.7} S_{\mathrm{c}}^{0.16}\left(\frac{R}{25.4}\right)^{0.903 A^{0.017}} W^{-0.19}
$$

where $Q_{\mathrm{p}}$ is peak runoff rate $\left(\mathrm{m}^{3} / \mathrm{s}\right) ; A$ is watershed area $\left(\mathrm{km}^{2}\right) ; S_{\mathrm{c}}$ is channel slope $(\mathrm{m} / \mathrm{km}) ; R$ is runoff volume $(\mathrm{mm})$; and $W$ is watershed shape parameter, defined as the square of watershed length over width $\left(\mathrm{m}^{2} / \mathrm{m}\right)$. Further details on the algorithms incorporated in the model can be found in Young et al. (1989).

Validation of the AGNPS model for sediment and water yield was demonstrated by Koelliker and Humbert (1989) on five watersheds in Kansas. Summer et al. (1990) linked AGNPS to a one-dimensional water body model (LAKE) in order to simulate watershed-lake system responses to land management and weather conditions. AGNPS has also been applied to target cost-effective cropland retirement programs that would reduce agricultural non-point- source pollution while maintaining adequate levels of land productivity (Kozloff et al. 1992).

Before determining the AGNPS input parameters, a grid system was superimposed on the watershed area. This grid was overlaid on maps drawn using GIS software that depicted distributions of channel systems, slopes, soil types, and land use. Other parameter values were determined in conjunction with, or solely through, the aid of available literature. A total of 295 cells covered the watershed, each with an area of 9.25 ha. Most of these cells were then subdivided to take into account the variation of model parameters within this relatively large cell size. This resulted in 974 divisions, 922 of which represented one quarter of a subdivided cell (2.3 ha each), and the remainder of which were whole cells.

Rainfall-runoff events from 1994 were used to calibrate AGNPS, while events from 1995 and 1996 were used to validate the model. The curve number was the only parameter varied for surface runoff calibration, since it is the single input parameter that influences runoff in AGNPS. Curve numbers were proportionally adjusted by trial and error from their initial values. SCS curve number antecedent moisture condition criteria as given in Schwab et al. (1981) were used for the initial simulations. For final model calibration and validation, the antecedent precipitation index (API) was calculated for each event, and used as a soil moisture indicator (eq. [3]). A relationship between curve number and API was then established.

The observed and predicted values were compared using the coefficient of performance, $\mathrm{CP}$ :

$$
\mathrm{CP}=\frac{\sum_{j=1}^{n}(Q(j)-O(j))^{2}}{\sum_{j=1}^{n}\left(O(j)-O_{\mathrm{avg}}\right)^{2}}
$$

where $O(j)$ is the $j$ th observed values, $O_{\text {avg }}$ is the mean of the observed values, $Q(j)$ is the $j$ th discharge value $\left(Q_{\mathrm{s}}\right.$ for simulated discharge and $Q_{\mathrm{o}}$ for observed discharge), and $n$ is the total number of events (James and Burgess 1982). The coef- 
ficient of performance approaches zero as the difference between observed and predicted values of the hydrologic quantities of interest becomes small.

\section{Results and discussion}

\subsection{Initial results}

Initial AGNPS simulations used the three antecedent moisture conditions associated with the SCS curve number method as described in Schwab et al. (1981). Table 2 shows the results of six initial storm simulations. The coefficients of performance for surface runoff and peak flow were 2.66 and 3.73, respectively. These values represent a poor performance. Surface runoff was generally the best-predicted hydrologic quantity. Average errors for surface runoff and peak flow were comparable $(47.1 \%$, and $43.4 \%$, respectively).

Peak flow was overpredicted by an average of $55.1 \%$ for four of the six events. Similarly, no clear pattern was observed with respect to surface runoff prediction for any of the three antecedent moisture conditions. AGNPS was therefore calibrated by proportionally altering curve numbers to provide better simulations. A relationship between curve number and antecedent precipitation index was developed in order to facilitate the calibration process.

\subsection{Calibration results}

All six rainfall-runoff events used in the initial simulation were used to calibrate AGNPS. In addition, another event was added (November 1, 1994) in order to include a simulation at the extreme low end of the antecedent precipitation index, i.e., an API of $3 \mathrm{~mm}$. Results of the calibration are presented in Table 2.

As previously mentioned, a relationship between the SCS curve number $(\mathrm{CN})$ and the antecedent precipitation index (API) was developed for each of the four SCS hydrologic soil groups and the five general land-use conditions (residential, pasture, grain, row crops, and forest). This resulted in 20 calibration curves that represent antecedent soil moisture as a continuous parameter. Each curve is governed by the following general mathematical form:

$$
\mathrm{CN}=a\left(b-\mathrm{e}^{-c \mathrm{API}}\right) \quad \text { for } 0 \leq \mathrm{API} \leq 100 \mathrm{~mm}
$$

where $a, b$, and $c$ are constants. Detailed values for each constant in all 20 equations are presented in Table 3 along with statistical information. These curves enable curve number selection for each input cell in the model.

These best-fit curves generally yielded correlation coefficients ( $r$-values) of 0.95 or greater. Although correlation values are artificially high because of the naturally narrow range of curve number variation, it would nevertheless seem that the calibration curves produced are as reasonable and good as can be expected. All 20 curves follow the same general pattern of exponential decay, with $\mathrm{CN}$ rising sharply as API increases from 0 to $30 \mathrm{~mm}$. Curve numbers then begin to level off as API reaches the 40 and $50 \mathrm{~mm}$ range, and eventually approaches $100 \mathrm{~mm}$ where $\mathrm{CN}$ remains essentially constant.

In order to test the validity of these calibration curves, curve numbers were selected from the graphs for a different 
Table 3. Values of constants and statistical parameters for calibration curves.*

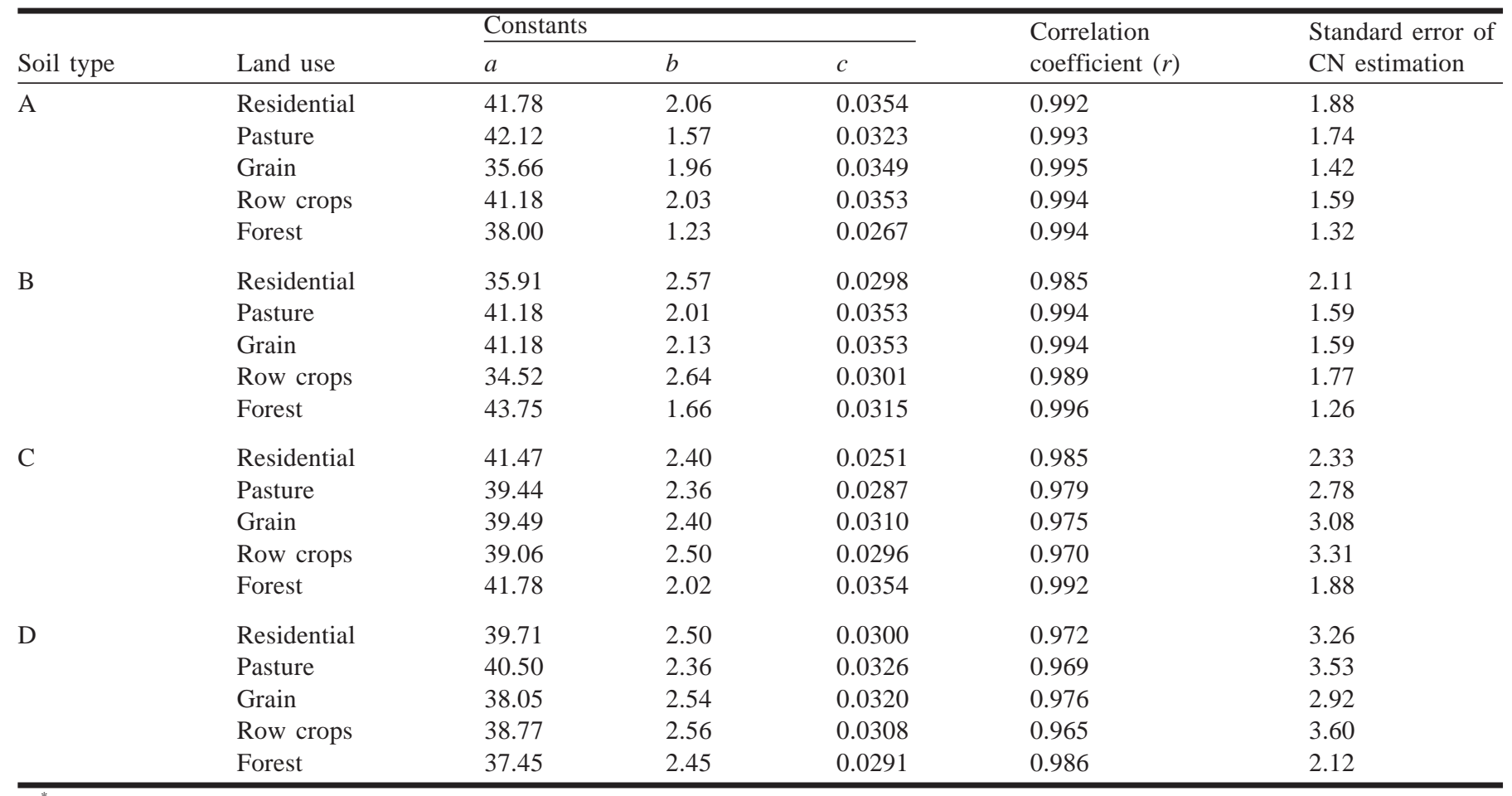

*All results obtained through the use of seven hydrologic events.

Table 4. AGNPS model validation results.

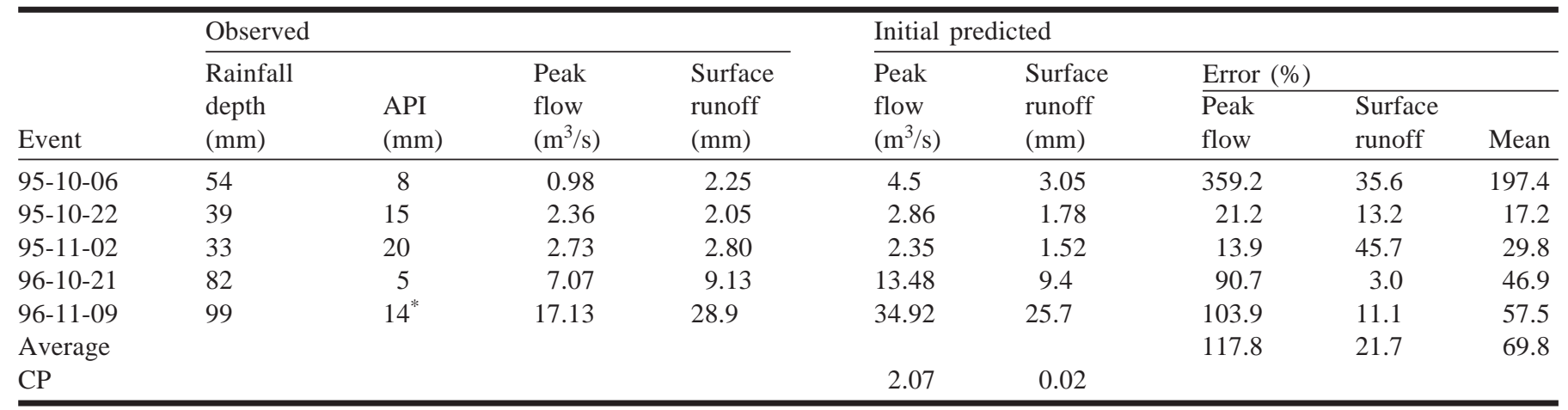

${ }^{*}$ API calculated with rainfall beyond $n=14$ days included (i.e., event of October $21-23, n=15-17$ ).

set of rainfall-runoff events of a known API. Results of this validation are presented in the following section.

\subsection{Validation results}

Five rainfall-runoff events were used to test the validity of the API vs. CN relationship. Curve numbers were selected using the calibration curves discussed in the previous section. Validation results are presented in Table 4.

Overall, the coefficient of performance for surface runoff was comparable to that calculated in model calibration (0.02). However, the coefficient of performance for peak flow rose to 2.07, compared with 0.43 for calibration. Mean percent error for all parameters and events was greater for validation $(69.8 \%)$ than for calibration $(25.3 \%)$. A large portion of this error was due to the poorly modeled event of Oc- tober 6, 1995, combined with the general inability of AGNPS to predict peak flow. If this event is omitted, average error falls to $37.9 \%$. Furthermore, average surface runoff estimation errors were $21.7 \%$, compared with $117.8 \%$ for peak flow.

The storms of October 22, 1995, and October 21 and November 9, 1996, were the best-simulated events. Surface runoff was predicted to within $3.0 \%$ for the large October 21,1996 , storm. The other relatively large storm, that of November 9, 1996, was simulated with comparable accuracy, with surface runoff estimated to within $11.1 \%$. It is important to note that the API for this event was calculated by including precipitation that had occurred 15-17 days prior to November 9. This increased the API from approximately 10 to $14 \mathrm{~mm}$ and, consequently, increased all curve numbers. 
This increase in API essentially represented the assumption that part of the heavy rainfall that began on October 21 contributed soil moisture prior to the November 9 storm. The relatively low evapotranspiration rates experienced during this time period would tend to support this assumption. The October 22, 1995, storm was also adequately simulated with surface runoff estimation producing an error of $13.2 \%$. Peak flow was overpredicted by $21.2 \%$ for this event. The two heavy storms of October 21 and November 9 produced peak flow simulation errors of $90.7 \%$ and $103.9 \%$.

In comparison with the three storms described above, the events of October 6 and November 2, 1995, were poorly modeled. Surface runoff for the October 6 storm was predicted to within $35.6 \%$. However, peak flow was grossly overestimated by $359.2 \%$. This extreme error can be attributed to the fact that the October 6 event was a complex storm with rainfall following an irregular pattern. This storm pattern coupled with a low initial stream flow $\left(0.15 \mathrm{~m}^{3} / \mathrm{s}\right)$ did not sharply increase flow, and yielded a peak flow of only $1.06 \mathrm{~m}^{3} / \mathrm{s}$. Both these factors cannot be taken into account by AGNPS. The November 2 event was simulated with similar accuracy, with runoff underpredicted by $45.7 \%$. Though the peak flow estimate for this event was underpredicted by only $13.9 \%$, it must be kept in mind that the underestimate of surface runoff (1.52 mm compared with $2.8 \mathrm{~mm}$ observed) made this small error possible. Since these two parameters are related, a more accurate surface runoff prediction would probably have resulted in an overestimate of peak flow similar to those witnessed in the simulation of other events. Inaccuracy in runoff prediction for this November event may be due to partial crusting or sealing of the mostly bare soil surface that is present after harvest. This factor may have decreased soil permeability.

Although the results reported are limited by the number of events, the simulations suggest some general patterns. Successful modeling requires use of antecedent precipitation index and associated curve numbers. The simulation of rainfall-runoff events at the St. Esprit watershed with respect to relative surface runoff prediction can be successfully achieved using AGNPS. The CREAMS equation used to estimate peak flow in AGNPS consistently overestimates this parameter.

\section{Conclusions}

The antecedent precipitation index was used to select curve numbers for input to the AGNPS hydrologic/water quality model in order to predict surface runoff and peak flow at the watershed outlet. Observed hydrologic data were obtained from water level and precipitation readings recorded at an automated gauging station.

Seven rainfall-runoff events were used to calibrate the model. Initial simulations were performed using the antecedent moisture conditions criteria incorporated in the SCS curve number method as a soil moisture indicator. The antecedent precipitation index was correlated to the SCS curve number. Final model calibration was performed using curve numbers selected with antecedent precipitation index as a soil moisture indicator. Five events were used in model validation. Observed and simulated output parameters for all 12 events were compared in order to determine the validity of the antecedent precipitation index and curve number relationship.

Initial simulation results produced average errors of $47.1 \%$ and $43.4 \%$ for surface runoff and peak flow, respectively. Corresponding coefficients of performance were 2.66 and 3.73, respectively. Final model calibration demonstrated considerable improvements. Average errors of $6.2 \%$ and $44.3 \%$ were observed for surface runoff and peak flow, respectively. Corresponding coefficients of performance decreased to 0.05 and 0.12 , respectively. Validation results produced an average error of $21.7 \%$ for surface runoff. Model validation for this parameter produced a low coefficients of performance of 0.02 . Peak flow simulation did not improve and yielded an average error and coefficients of performance of $117.8 \%$ and 2.07 , respectively.

The use of antecedent precipitation index as a soil moisture indicator, as related to curve number, improved model simulation. This method demonstrated AGNPS to be a valid tool for watershed modeling on the St. Esprit basin when surface runoff volume was considered. However, the model generally overpredicted peak flow. Since surface runoff $(R)$ is the only parameter within the CREAMS equation that varies with each event, and since surface runoff was generally well predicted, it must therefore be concluded that the CREAMS equation is not applicable to peak flow prediction on this basin.

AGNPS performed best when events between June 1 and November 1 were simulated. Poorer model performance was observed when complex storms and events occurring during periods of relatively cold climatic conditions (early spring and fall events) were simulated. Several factors can explain these shortcomings. First, the AGNPS model structure does not provide for continuous update of input values as rainfall-runoff events progress with time. Second, AGNPS cannot simulate snowmelt or frozen soils. Curve number calibration specifically for climatic and land use conditions in early spring and late fall may improve model performance for these seasons. Alternately, release of a continuous version of AGNPS may enable such simulations. In the meantime, it is hoped that continued monitoring of the St. Esprit watershed will enlarge the hydrologic database and confirm this application of the antecedent precipitation index.

\section{Acknowledgments}

This project was supported by the Société d'agriculture de Montcalm under funding from the Canada-Quebec Green Plan of Agriculture and Agri-Food Canada and the Ministère de l'agriculture, de l'alimentation et des pecheries du Québec.

\section{References}

Bales, J., and Beston, R.P. 1982. The curve number as a hydrologic index. In Rainfall-runoff relationships. Edited by V.P. Singh. Water Resources Publications, Littleton, Colo.

Bruce, J.P., and Clark, R.H. 1966. Introduction to hydrometeorology. Pergamon Press, Oxford, United Kingdom. pp. 252-257.

Chen, C. 1981. An evaluation of the mathematics and physical significance of the Soil Conservation Service curve number procedure for estimating runoff volume. In Rainfall-runoff relation- 
ships. Edited by V.P. Singh. Water Resources Publications, Littleton, Colo.

Enright, P. 1988. Simulation of rainfall excess on flat rural watersheds in Quebec. M.S. thesis, Department of Agricultural Engineering, McGill University, Montreal, Que.

Foroud, N. 1978. A flood hydrograph simulation model for watersheds in southern Quebec. Ph.D. thesis, Department of Agricultural Engineering, McGill University, Montreal, Que.

Hauser, V.L., and Jones, O.R. 1991. Runoff curve numbers for the southern high plains. Transactions of the ASAE, 34(1): 142-148.

Hawkins, R.H. 1979. Runoff curve numbers from partial area watershed. Journal of the Irrigation and Drainage Division, 105: 375-389.

Hjelmfelt, A.T., Jr., Kramer, L.A., and Burwell, R.E. 1982. Curve numbers as random variables. In Rainfall-runoff relationships. Edited by V.P. Singh. Water Resources Publications, Littleton, Colo.

Hoang, V.D. 1979. Études du coefficient de ruissellement sur des petits bassins versants des regions de l'Estrie et des Bois Francs. Direction générale des eaux, Service de l'hydrométrie, Ministère de l'Environnement dur Québec, Publication HP-49.

James, L.D., and Burgess, S.J. 1982. Selection, calibration and testing of hydrologic models. In Hydrologic modeling of small watersheds. Edited by C.T. Haan, H.P. Johnson, and D.L. Brakensiek. ASAE, St. Joseph, Mich., pp. 437-472.

Knisel, W.G. (Editor). 1980. CREAMS: a field-scale model for chemicals, runoff and erosion from agricultural management systems. Conservation Research Report No. 26, South East Area, U.S. Department of Agriculture, Washington, D.C.

Koelliker, J.K, and Humbert, C. E. 1989. Applicability of AGNPS model for water quality planning. ASAE Paper No. 89-2042, Québec, Que.

Kozloff, K., Taff, S.T., and Wang, Y. 1992. Microtargeting the acquisition of cropping rights to reduce nonpoint source water pollution. Water Resources Research, 28(3): 623-628.

Lapp, P. 1996. The hydrology and water quality of an intensive agricultural watershed in Quebec. M.S. thesis, Department of Agricultural Engineering, McGill University, Montreal, Que.

Leonard, R.A., Knisel, W.G., and Still, D.A. 1986. GLEAMS: groundwater loading effects of agricultural management systems. ASAE Paper No. 86-2511, Chicago, Ill.

Madramootoo, C.A., and Enright, P. 1988. Applicability of the Soil Conservation Service equations for runoff predictions in the Ottawa-St. Lawrence Lowlands. Canadian Journal of Civil Engineering, 15(5): 759-765.

MEF. 1995. Statistiques annuelles et mensuelles - Station 7017380 (St. Jacques). Direction des réseaux atmospheriques, Ministère de l'Environnement et Faune du Québec.

Monfet, J. 1979. Evaluation du coefficient de ruissellement à l'aide de la méthode SCS modifiée. Service de l'hydromètrie, Ministere de l'Environnement du Québec, Publication HP-51.

Schwab, G.O., Prevert, R.K., Edminster, T.W., and Barnes, K.K. 1981. Soil and water conservation engineering. John Wiley \& Sons, Inc., New York, N.Y.
Sheridan, J.M., and Shirohammadi, A. 1986. Application of curve number procedure on coastal plain watersheds. ASAE Paper No. 86-2505, Chicago, Ill.

Smith, R.E., and Eggert, K.G. 1978. Discussion: Infiltration formula based on SCS curve number. Journal of the Irrigation and Drainage Division, 104: 462-464.

Smith, R.E., and Williams, J.R. 1980. Simulation of surface water hydrology. In CREAMS - a field scale model for chemicals, runoff, and erosion from agricultural management systems. Conservation Research Report 26, Agricultural Research Service, U.S. Department of Agriculture, Washington, D.C.

Steichen, J.M. 1983. Field verification of runoff curve numbers for fallow rotations. Journal of Soil and Water Conservation, 38(6): 496-499.

Summer, R.M., Alonso, C.V., and Young, R.A. 1990. Modeling linked watershed and lake processes for water quality management decisions. Journal of Environmental Quality, 19: 421-427.

U.S. Department of Agriculture, Soil Conservation Service. 1972. Hydrology. In National engineering handbook. Washington, D.C. pp. 10.5-10.6.

Yoo, K.H., Yoon, K.S., and Soileau, J.M. 1993. Runoff curve numbers determined by three methods under conventional and conservation tillages. Transactions of the ASAE, 36(1): 57-63.

Young, R.A., Onstad, C.A., Bosch, D.D., and Anderson, W.P. 1985. Agricultural nonpoint surface pollution models (AGNPS) I and II model documentation. Pollution Control Agency, St. Paul, Minn., and Agricultural Research Service, U.S. Department of Agriculture, Washington, D.C.

Young, R.A., Onstad, C.A., Bosch, D.D., and Anderson, W.P. 1987. Agricultural nonpoint source pollution model: a large watershed analysis tool. Conservation Research Report 35, Agricultural Research Service, U.S. Department of Agriculture, Washington, D.C.

Young, R.A., Onstad, C.A., Bosch, D.D., and Anderson, W.P. 1989. Agricultural nonpoint source pollution model for evaluating agricultural watersheds. Journal of Soil and Water Conservation, 44(2): 168-173.

Young, R.A., Onstad, C.A., Bosch, D.D., and Anderson, W.P. 1994. Agricultural nonpoint source pollution model, Version 4.03, AGNPS user's guide. Pollution Control Agency, St. Paul, Minn., and Agricultural Research Service, U.S. Department of Agriculture, Washington, D.C.

\section{List of symbols}

AGNPS: agricultural non-point source (a hydrologic model)

AMC: antecedent moisture condition

API: antecedent precipitation index

$\mathrm{CN}$ : curve number

$\mathrm{CP}$ : coefficient of performance

SCS: soil conservation service 